\title{
Congenital Brusellosis in a Preterm Neonate
}

\section{Erken Doğan Bir Bebekte Doğumsal Bruselloz}

\author{
Yalçın Çelik', Hülya Halis', Selvi Gülaşı' ${ }^{1}$ Aytuğ Atıcı' ${ }^{1}$ Necdet Kuyucu² \\ ${ }^{\prime}$ Department of Pediatric Health and Diseases, Department of Neonatology, Mersin University School of Medicine, Mersin, Turkey \\ ${ }^{2}$ Department of Pediatric Health and Diseases, Department of Pediatric Infection Diseases, Mersin University School of Medicine, Mersin, Turkey
}

\begin{abstract}
Brucellosis is a worldwide infectious disease caused by Brucella spp. bacteria. The present case presents a newborn of 24-week gestastational age who was intubated after the delivery due to respiratory disstress and admitted to the NICU. The patient had clinical signs similar to sepsis and Brucella melitensis grew in the blood culture. After the growth of Brucella melitensis in the blood culture, mother of the patient was examined for brucellosis and she was found to have brucellosis. We reported this case since congenital Brucellosis cases are very rare in the literature.
\end{abstract}

Keywords: Congenital brucellosis, newborn, preterm labour

\section{Introduction}

Although brucellosis is primarily an animal disease, it can be seen in humans who directly contact infected animals or who consume products that are not well-cooked $(1,2)$. Transmission of Brucella from human to human is rare, however, it has been reported that it can be transmitted by blood transfusion, bone marrow transfusion and sexual intercourse (3-5). In addition, although rare, it can be transmitted via the placenta before delivery from the infected mother to the baby, via blood or other fluids during labor and via breast milk after birth $(4,6,7)$. A case involving the transmission of Brucella from the mother to the baby before $r$ during labor is presented.
Özet

Bruselloz Brucella türü bakterilerle oluşan ve tüm dünyada önemli sağlık sorunlarına neden olan bir enfeksiyon hastalığıdır. Burada 24. gebelik haftasında doğan ve doğumun ardından solunum sıkıntısı nedeniyle entübe edilerek yenidoğan yoğun bakım ünitesine yatırılan bir olgu sunulmuştur. Bu olguda yenidoğan yoğun bakım ünitesinde yattığı dönemde klinik sepsis bulguları nedeniyle alınan kan kültüründe Brucella melitensis üremesi tespit edilmiştir. Bu bulgunun ardından anne de bruselloz yönünden tetkik edilmiş ve anne de bruselloz tanısı almıştır. Doğumsal bruselloz olgularının tıbbi yazında oldukça nadir olarak bildirilmiş olması nedeniyle bu olgu sunulmuştur.

Anahtar Kelimeler: Doğumsal bruselloz, erken doğum, yenidoğan

\section{Case Report}

A premature 7-day old girl was admitted to the newborn intensive care unit of our hospital due to respiration stress. The baby had been entubed and was admitted to the newborn intensive care unit after labor in another center, where she was born. However, her general condition worsened and was referred to our hospital on the seventh day. The baby was the $5^{\text {th }}$ living child from the $5^{\text {th }}$ pregnancy of the 25 -year old mother, who lived in a rural region in the Southeast Anatolia, had not been regularly followed up during pregnancy. The baby had beewasn born $580 \mathrm{~g}$ at the $24^{\text {th }}$ week of pregnancy via the vaginal way, was entubed as soon as she was born, surfactan 
was administered, then was taken into the newborn intensive care unit in the same center, where she was monitored with a mechanical ventilator. Initially, intravenous ampicillin and gentamucin was started but when the general condition did not improve, the gentamycin treatment was stopped on the third day and intravenous cefotaxime treatment was started. On the seventh day her general condition still worsened and the baby was referred to our hospital for further analyses and treatment. When admitted to our hospital, the general condition of the baby was not good; her weight was $570 \mathrm{~g}$ (10-25\%), height was $31 \mathrm{~cm}$ (10-25\%), head circumference was $21.5 \mathrm{~cm}$ (10-25\%), body temperature was $36.4^{\circ} \mathrm{C}$, blood pressure was $41 / 21 \mathrm{mmHg}$, capillary refilling time was four seconds and heart rate was 180/min. Crepitant rales could be heard in both of her lungs. The abdomen appeared normal, the liver could be felt by hand as $3 \mathrm{~cm}$ under the costa. The external genital structures had the appearance of a girl. The total blood count of the patient was as follows: hemoglobin $15.9 \mathrm{~g} / \mathrm{dL}$, hematocrit $42.2 \%$, white blood cell count $28.090 / \mu \mathrm{L}$, thrombocyte count $73.000 / \mu \mathrm{L}$. In the peripheral blood smear, there were $62 \%$ neutrophils, $36 \%$ lymphocytes, $2 \%$ monocytes. The biochemical analyses were as follows: urea $183 \mathrm{mg} / \mathrm{dL}$, creatinine $0.9 \mathrm{mg} / \mathrm{dL}$, sodium $142 \mathrm{mEq} / \mathrm{L}$, potassium $5.2 \mathrm{mEq} / \mathrm{L}$, aspartate aminotransferase (AST) $25 \mathrm{U} / \mathrm{L}$, alanine aminotransferase (ALT) $7 \mathrm{U} / \mathrm{L}, \mathrm{C}$-reactive protein (CRP) $1 \mathrm{mg} / \mathrm{L}$, procalcitonin 0.9 $\mathrm{ng} / \mathrm{mL}$. In the analyses made in the center where the baby was born, there was no thrombocytopenia. The intravenous ampycillin and cephotaxim treatments, which were previously started, were continued; dopamine and dobutamine were started. Oxygenation and carbon dioxide release could not be ensured with traditional artificial respiration methods, so high speed vibration ventilation was used. On the third day of hospitalization, the antibiotics were changed to intravenous vancomycin, meropenem and flukonazol. The thrombocytopenia of the patient became obvious and she was administered thrombocyte suspension $(50.000 / \mu \mathrm{L})$. There was disorder in blood coagulation tests, so she was administered fresh frozen plasma. On the $4^{\text {th }}$ day of hospitalization, anemia was detected (hematocrit 28\%), and the baby was administered erythrocyte suspension. On the $7^{\text {th }}$ day of hospitalization, again thrombocyte suspension was administered due to thrombocytopenia and on the $14^{\text {th }}$ day again erythrocyte suspension was administered due to anemia. On the assays conducted on the $24^{\text {th }}$ day of hospitalization, there was no anemia and thrombocytopenia. CRP and procalcitonine values were normal and there was no growth in the blood culture, which ad been repeated three times up to then. Upon these findings, the vancomycin, meropenem and flukonazol treatments were completed to 21 days and were ceased. When the baby was
34 days old, dexamethasone $(0.15 \mathrm{mg} / \mathrm{kg} /$ day $)$ administration was started and was continued for four days since the artificial respiration requirement continued. At this time, Klebsiella pneumoniae growth was detected in the tracheal tube tip culture and the patient was administered intravenous ampicillin and ciprofloxacin. When the baby was 38 days old, her general condition rapidly deteriorated, blood pressures decreased, capillary refilling time became longer, abdomen dystension developed, vomiting occurred and clinical sepsis was considered. The assays were as follows upon this: white blood cell count $4150 / \mu \mathrm{L}$, thrombocyte count $20.000 / \mu \mathrm{L}, \mathrm{CRP} 63.7 \mathrm{mg} /$ $\mathrm{dL}$, procalcitonine $>100 \mathrm{ng} / \mathrm{dL}$. Late sepsis was considered for meningitis and lumber puncture was thought of but it could not be carried out because her general condition was not stable and was being monitored by high speed vibration ventilation. At this time, Brucella melitensis growth was observed in the blood culture of the baby, Bruccella agglutination tests were carried out and high titer positivity (1/640) was detected. With these clinical and laboratory findings, brucellosis diagnosis was given and ampicillin treatment was stopped and intravenous gentamycin was added to the treatment besides the ciprofloxacin treatment that the patient was being given. $\mathrm{Ci}$ profloxacin and gentamycin administration was continued for 21 days. There was no growth in the blood cultures taken after the treatment. The family was recommended to have assays made for brucellosis in the city they lived in, as a result of this, the mother was diagnosed as brucellosis and her treatment was started. Since the mother was living in a far away city to our hospital, the baby was not breast fed and had not contacted the mother. When the baby was fifty two days old, she no longer needed artificial respiration and was discharged when she was 126 days old. Currently she is 4 years old and is being followed up; she has no diseases and no disabilities.

\section{Discussion}

Brucellosis is an infectious disease seen worldwide, especially in the Mediterranean countries, Latin America, Africa, middle Asia and Middle East $(2,6,8)$. Developed countries have achieved control of the disease to a great extent, however, brucellosis is still very important in developing countries $(6,8)$. In Turkey, brucellosis is frequently encountered in the Southeast Region, where raw mik and its products are consumed and animal husbandry is common (1). The patient in this case report was referred to our hospital from a province of the Southeast Region and the baby's mother was consuming raw milk products.

Brucella is a small, immobile, gram-negative coccobacillus $(1,3,6)$. The species that can infect humans are generally $B$. abortus, $B$. melitensis and $B$. suis. However, the most frewuently 
encountered pathogen is B. melitensis (9). In the present case also the responsible agent was found to be $B$. melitensis.

Brucella is generally causes a continuing infection in animals, settles in the reproductive organs of animals and leads to miscarriages and sterility (10). A substance having a carbohydrate structure, named erythritol, found in the placenta of animals such as sheep, goat and pig facilitates the growth of brucella $(3,4,6)$. There is no erythritol in human placenta and thus, the significance of brucella in miscarriage or preterm labor of humans is being disputed $(3,4,6)$. However, it has been reported, although rarely, that Brucella is detected in the placenta and the amnion fluid of pregnant women with brucellosis, and their stillborn fetuses (6). In the present case, the question whether the reason for preterm labor is the brucellosis of the mother may arise. However, in the present caser, no culture was taken from the amnion fluid nor from the placentas, in addition, there was no Brucella growth in the blood cultures taken from the baby in early stages. Thus, it is difficult to associate the reason of preterm labor in the present case with a Brucella infection.

Brucella infections in the newborn are rare and are reported as case reports in medical literature. In a recent report by Doğan et al. there was prematurity, sepsis, respiratory stress and hepatomegaly and Brucella spp. growth in the blood culture (11). Brucella agglutination tests were carried out in the mother and the baby and a high titer of positivity $(1 / 1280$ and $1 / 640$ respectively) was detected. The baby was administered intravenous cotrimoxazole and rifampicin for three weeks, then the treatment was completed to six weeks orally and the baby was discharged as healthy. In the case, Doğan et al. considered that the Brucella was transmitted to the baby by the mother through the placenta since there was growth in the blood culture taken from the baby on the first day.

In another case reported by Aydın et al. , the baby was born at 25 weeks and was $810 \mathrm{~g}$ and was admitted to the newborn intensive care unit due to respiratory stress; there was B. melitensis on the fifth day in the blood culture (9). Upon this finding, the mother was examined was there $B$. melitensis growth was also detected in her blood culture and $1 / 320$ positivity was detected in the Brucella agglutination test. According to the results of the antibiogram, firstly intravenous cefotaxim and rifampicin were administered to the baby; however, when liver enzymes increased on the second day, rifampicin was stopped and the treatment was continued with trimethoprim and sulfamethoxazole. Unfortunately, the baby died when it was 14 days old. Aydın et al. believed that the Brucella was transmitted via the placenta since $B$. melitensis grew in the blood culture taken on the first days, since the baby was breast fed and since it did not have any blood transfusion.
Akçakuş et al. reported B. melitensis growth in blood culture in two cases where they conducted blood transfusion due to hyperbilirubinemia (12). In these two cases, brucellosis was not detected in the mothers and it was believed that the Brucella was transmitted via the transfused blood. Another case where Brucella was transmitted through blood transfusion was reported by Al- Kharfy et al. (13). The case was born at 24 weeks and was being monitored in the newborn intensive care unit; in the postmenstrual $45^{\text {th }}$ week, decrease in activity, decrease in weight gain and slight fever $\left(37.6-38^{\circ} \mathrm{C}\right)$ was detected. In the blood culture taken, there was $B$. melitensis growth and $1 / 160$ positivity in the rucella agglutination test. With these findings, cotrimoxazole and rifampicin administration was started and it was reported that after six weeks of treatment the baby had completely recovered. There was no brucellosis in the family and the blood cultures and serological tests of the family members were found negative for Brucella. Upon this, it was considered that the Brucella could have been transmitted by blood transfusion since the baby was administered erythrocyte suspension ten times and the donors were examined for brucellosis. There were clinical findings indicating brucellosis in one of the donors but since this donor was abroad, the necessary examinations could not be carried out.

Ceylan et al. recently reported a newborn Brucellosis case, believed to be transmitted by breast milk (7). The case was born at 28 weeks; when the case was three weeks old, the baby and the mother were examined for brucellosis since the weight gain of the baby was inadequate and the mother has brucellosis in the last month of pregnancy. The Brucella tube agglutination tests carried out in the mothers serum, breast milk and the baby's serum were found to be positive $(1 / 1280$, $1 / 640$ and $1 / 160$ respectively). Upon these findings, brucellosis inflammation in the mother was considered, breast feeding of the baby was stopped; diagnosing brucellosis in the baby, trimethoprime-sulfamethoxazole and rifampicin administration to the baby was started. Ceylan et al. reported that after six weeks of treatment, the baby was healthy and discharged.

In the present case, clinical sepsis findings were observed as the baby was 38 days old in the newborn intensive care unit; in the laboratory analyses, increase in leucopenia, thrombocytopenia, CRP and procalcitonin values were detected and then, unexpectedly, B. melitensis grew in the blood culture. Brucella agglutination tests were carried out and high titer positivity was detected. Upon diagnosing brucellosis in the baby, the mother was also examined for Brucella infection was diagnosed as brucellosis. We maintain that that $B$. melitensis was transmitted from the mother to the baby since Brucella infection was detected both in the baby and the mother. On the other hand, there was no B. melitensis growth in the baby in 
the blood cultures taken at an early stage after labor. However, the reason for this may be the fact that the incubation period of $B$. melitensis may be as long as two months (14). Moreover, since our case was never breastfed, we maintain that the transmission was not by breast milk. On the other hand, that the case was administered many blood products while it was hospitalized in the newborn intensive care unit suggested that the transmission had been by these blood products. Therefore we wanted to examine the donors for brucellosis but it was not possible to reach them.

Various drugs may be used in the treatment of brucellosis. Antibiotics that can enter the cell and that can be effective in acidic medium must be used since $B$. melitensis settles in the cells phagocytosis is acidic $(1,8)$. Treatment with a single drug is not recommended as the recurrence probability is high $(1$, 8). For treatment of children, generally, trimethoprim-sulfamethoxazole, rifampicin and aminoglucosides are preferred (15). In the present case, trimethoprim-sulfamethoxazole and rifampicin treatment could have been chosen but our patient was being administered intravenous ciprofloxacin treatment before brucellosis diagnosis. Since some studies showed that fluoroquinolones are also effective in treatment, intravenous gentamycin was added to this ciprofloxacin treatment and was continued for 21 days (16). With this treatment, the clinical findings of the baby improved and there was no more growth in blood cultures.

In conclusion, we maintain that the newborn in regions of Turkey where brucellosis is frequent are under the risk of Brucella infection. It seems important with respect to the health of the newborn that informing the pregnant women on consuming well boiled milk and its products in regions where brucellosis is common.

Informed Consent: Written informed consent was obtained from the parent of the patient.

Peer-review: Externally peer-reviewed.

Author Contributions: Concept - $Y C ̧, H H$; Design - AA, YÇ; Supervision - AA, NK; Materials - AA, YÇ, SG, NK; Analysis and/or interpretation YÇ, HH, SG; Literature review - AA, YÇ, SG, HH, NK; Writer - YÇ, HH; Critical review - NK

Conflict of Interest: No conflict of interest was declared by the authors.

Financial Disclosure: The authors declared that this study has received no financial support.

\section{References}

Çelebi S, Hacımustafaoğlu M, Demirtaş F, Salı E, GülÜ, Özel M. Çocukluk çağında bruselloz. J Pediatr Inf 2011;5:59-62.

2. Mosayebi Z, Movahedian AH, Ghayomi A, Kazemi B. Congenital brucellosis in a preterm neonate. Indian Pediatr 2005;42:599-601.

3. Elshamy $M$, Ahmed $A$. The effects of maternal brucellosis on pregnancy outcome. J Infect Dev Ctries 2008;2:230-4.

4. Mesner O, Riesenberg K, Biliar N, et al. The many faces of human-tohuman transmission of brucellosis: congenital infection and outbreak of nosocomial disease related to an unrecognized clinical case. Clin Infect Dis 2007;45:e135-40.

5. Pouloua A, Markoua F, Xipolitosa I, Skandalakis PN. A rare case of Brucella melitensis infection in an obstetrician during the deliveryof a transplacentally infected infant. J Infect 2006;53:e39-41.

6. Karcaaltincaba D, Sencan I, Kandemir O, Guvendag-Guven ES, Yalvac $S$. Does brucellosis in human pregnancy increase abortion risk? Presentation of two cases and review of literature. J Obstet Gynaecol Res 2010:36:418-23

7. Ceylan A, Köstü M, Tuncer O, Peker E, Kırımi E. Neonatal brucellosis and breast milk. Indian J Pediatr 2012;79:389-91.

8. Tagupsky P. Neonatal brucellosts: rare and preventable. Ann Trop Paediatr 2010;30:177-9.

9. Aydin B, Dilli D, Zenciroğlu A, et al. Comparison of a rapid bed-side test with a central laboratory analysis for C-reactive protein in newborn infants with suspicion of sepsis. Clin Lab 2013;59:1045-51.

10. Díaz Aparicio E. Epidemiology of brucellosis in domestic animals caused by Brucella melitensis, Brucella suis and Brucella abortus. Rev Sci Tech 2013;32:43-51.

11. Dogan DG, Aslan M, Menekse E, Yakinci C. Congenital brucellosis: case report. Ann Trop Paediatr 2010;30:229-31.

12. Akçakuş M, Esel D, Cetin N, Kisaarslan AP, Kurtoğlu S. Brucella melitensis in blood cultures of two newborns due to exchange transfusion. Turk $J$ Pediatr 2005;47:272-4.

13. Al-Kharfy TM. Neonatal brucellosis and blood transfusion: case report and review of the literature. Ann Trop Paediatr 2001;21:349-52.

14. Traxler RM, Lehman MW, Bosserman EA, Guerra MA, Smith TL. A literature review of laboratory-acquired brucellosis. J Clin Microbiol 2013;51:3055-62.

15. Rubach MP, Halliday JE, Cleaveland S, Crump JA. Brucellosis in lowincome and middle-income countries. Curr Opin Infect Dis 2013;26:40412.

16. Teker D, Tanir G, Ozmen S, Teke TA, Keles S, Bostancl I. Treatment of brucellosis in a young child with trimethoprim/sulfamethoxazole anaphylaxis. J Infect Public Health 2014;7:553-6. 